\title{
Impact of petroleum and non-petroleum indices on financial development in Oman
}

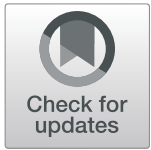

\author{
Faris Nasif Alshubiri ${ }^{1 *}$, Omar Ikbal Tawfik ${ }^{2}$ and Syed Ahsan Jamil ${ }^{3}$
}

\author{
* Correspondence: falshubiri@du. \\ edu.om \\ ${ }^{1}$ Department of Finance and \\ Economics, College of Commerce \\ and Business Administration, Dhofar \\ University, P.O. Box: 2509, 211 \\ Salalah, Sultanate of Oman \\ Full list of author information is \\ available at the end of the article
}

\begin{abstract}
This study analyzes the impact of petroleum and non-petroleum indices on the financial development of the Sultanate of Oman from 1978 to 2017. To this end, it uses the petroleum proxy of oil rents (\% of gross domestic product, GDP) and the non-petroleum proxy of industry (including construction) value added (\% of GDP); agriculture, forestry, and fishing value added (\% of GDP); and services value added (\% of GDP) to determine the effect on financial development, measured by the amount of domestic credit extended to the private sector by banks (\% of GDP). It applies an autoregressive distributed lag (ARDL) model. The long-term equation illustrates that the agriculture and industry GDPs have a negative and significant relationship with domestic credit in Oman. However, the oil and service sector GDPs promote financial development. The short-term equation illustrates that the oil, agricultural, and service sectors have positive and significant effects on domestic credit. The conclusion is that the economy of Oman is still in the first phase of economic diversification. Accordingly, the government should use oil revenues to develop various non-oil industrial sectors. This would enhance the country's competitiveness in the global economy and positively contribute to improving the liquidity of the banking sector for stimulating credit at the macroeconomic level.
\end{abstract}

Keywords: Petroleum index, Non-petroleum index, Financial development, ARDL model, Oman

JEL classification: $B 26,013,044, G 21, K 32, B 22$

\section{Introduction}

Natural resources, specifically crude petroleum, play a vital role in the economic development and sustainable growth of countries. Petroleum and non-petroleum wealth are major sources of government revenue for many economies worldwide (Basnet and Upadhyaya 2015), as they have a pivotal role in shaping a country's internal policy through economic programs that are compatible with its economic and oil price policies (Lardic and Mignon 2008).

Among natural resources, petroleum and non-petroleum wealth determine a country's economic policy and trade relations with other countries, especially imports and exports and the balance of payments position (Nkomo 2006). Therefore, many oildependent countries, including Oman, rely heavily on oil sector revenue to finance infrastructure projects and achieve sustainable development. However, there are concerns regarding the sustainability oil wealth, resulting from the decline in revenue

(c) The Author(s). 2020 Open Access This article is distributed under the terms of the Creative Commons Attribution 4.0 International License (http://creativecommons.org/licenses/by/4.0/), which permits unrestricted use, distribution, and reproduction in any medium, provided you give appropriate credit to the original author(s) and the source, provide a link to the Creative Commons license, and indicate if changes were made. 
during the recent global financial crisis, which has led to all Gulf Cooperation Council (GCC) countries focusing on the development of non-oil activities. The global financial crisis of 2007made many oil-reliant countries realize the perils of a global economic slowdown and its negative impact on their own economic growth, which could potentially lead to social unrest and upheaval (Ajmi et al. 2015). Therefore, these countries have realized the urgent need to diversify their revenue sources and reduce their dependence on the petroleum sector (Oladosu 2009).

Petroleum-related activities, especially for oil-producing and oil-exporting countries, are important in shaping the main source of income for these countries. However, the recent global financial crisis led these countries, including Oman, to consider how to distribute income from these sources to non-oil activities to overcome the fall in their income because of the drop in oil prices in recent years, which led to a decrease in the total income of these countries. Consequently, this income decline has led to the collapse of these countries' infrastructure plans, delaying the improvement of the economic and competitiveness indices of such countries and hindering the process of their sustainable development. The success of a country is measured by how it can overcome financial and economic crises that increase the risks related to its environmental resources.

Oman's growth and welfare are also heavily dependent on oil wealth. The risks surrounding oil price fluctuations have cautioned the government to consider actively promoting non-oil environmental resources through industrial diversification and service and financial infrastructure development (Iwayemi and Fowowe 2011). Presently, given the low petroleum prices, revenue has been severely affected, which has led to a large budget deficit even in 2018. The promotion of petroleum and non-petroleum activities contributes directly as well as indirectly to the sustainable development of domestic credit (Ibrahim et al. 2014) Therefore; the banking sector plays a crucial role in the country's financial and economic development.

Oman is still committed to an economic diversification plan and to reducing its reliance on the oil sector, but oil prices have begun to affect its efforts toward the development of the non-oil sector. That is, government and private spending declined in 2016, while the value of approved projects reduced by USD 7 billion in 2016 (Central Bank of Oman 2017). If the expected oil prices remain below the parity price, there will be greater pressure on Oman's reserves. The fiscal burden from 2016, 2017, and 2018 are greatly affecting the economic growth of the country. To continue to finance the deficit, the government has resorted to foreign loans.

As such, Oman, represented by its Central Bank, has to find solutions to the budget deficit caused by the decline in oil prices, which has reduced the main source of revenue for the country. The Central Bank of Oman (2017) has taken the following steps. First, Oman has managed to borrow OMR 5.5 billion internationally to finance the fiscal deficit of 2016 through international bonds and syndicated loans, which were supported by its credit rating. Although the level of government debt is still relatively low compared to that of neighboring countries, it is expected to increase in the future. Second, in light of the decline in oil prices, the government reduced current and investment expenditures, supported by the revenue, which aided the financial situation in 2018 (e.g., increased gasoline prices, government fees, and corporate taxes, and reduced spending in government institutions). Third, small- and medium-sized enterprises also 
play a prominent role in the growth of the economy, and prudent credit regulation could leave the industry in good health. Fourth, a flexible liquidity policy puts risks at equilibrium to determine the direction of oil prices over the medium term, which governs the performance of the banking sector. Finally, several infrastructure projects began in 2018 and the government once again aimed to achieve a 3\% growth by the end of fiscal year 2018.

Finance and banking are considered important for developing other sectors. However, the development of bank credit is not sufficient to classify a country as advanced; rather, it is a reflection on long-term survival through the provision of competitive services to customers. A long-term view explains the concern of Oman regarding sustainable development. Recently, all GCC countries have starting working towards achieving sustainable development goals.

To date, no study has investigated both the petroleum and non-petroleum activities in GCC countries and their impact on financial development, as proxied by bank credit. This study aims to address this literature gap by focusing on Oman over the period 1978 to 2017.Its importance lies in its aim to analyze the activities of the oil and nonoil sectors in an attempt to highlight which activities have a positive and significant impact on the financial development of Oman as well as the reasons behind the diversification of its industrial sectors.

This remainder of this paper is organized as follows. The subsequent two sections review the related literature and present the background of the topic. The fourth section presents the research methodology and the proposed models, and the fifth section the empirical results and their interpretation. Finally, the last section draws the conclusions and presents policy implications.

\section{Literature review}

Several previous studies such as those of Ajmi et al. (2015), Calza et al. (2006), Jiménez et al. (2009), Köhler (2015), and Neelam (2014) have focused on environmental and energy resources in the analysis of "environmental wealth" and their relationships with the growth of a country's sources of revenue. Oil and gas resources play an important role in countries where oil is the main resource (Cunado and De Gracia 2005). The linear relationship between oil prices and the gross domestic product (GDP) began to first lose importance when during the drop in oil prices in the second half of the 1980s and had a positive impact on economic activities; however, this impact was smaller than expected by linear models (Lardic and Mignon 2008). Volatility in energy prices has a significant impact on the economic environment, as found by Gabor et al. (2017), in that energy prices affect the savings and preservation of other energy sources. As such, many developed countries have tried to change and update their policies on how to exploit environmental resources. The impact of these policies percolates to the microeconomic level and, thus, many of the decisions of a country become dependent on the existence of an astute environmental management system (Lane and Milesi 2007). Therefore, countries are quickly developing new policies and procedures in accordance with the changes in their environments, especially technological advancements and sources of renewable energy (Oladosu 2009). Chen et al. (2017) found that the best ecosystem is based on measuring performance constantly and is selected from several systems within a complex environment. 
Ajmi et al. (2015), Basnet and Upadhyaya (2015), and Cunado and De Gracia (2005) among others suggested that changes in oil prices are significantly related to the various economic activities in a country and also affect the degree of bank credit. These changes cause differences in the trade balance of the oil exports and imports of countries (Lane and Milesi 2007) and the increase in oil prices contributesto improving the exports from all economic sectors and reduces imports. According to Brown and Yücel (2002) and Ferderer (1996), high oil prices are hampering the macroeconomic activity; whereas Ibrahim et al. (2014) pointed that an increase in oil prices positively affected the Nigerian economy by increasing export revenues. At the same time, it exacerbated the uncertainty in the economy because of its impact on financial instability and the weak implementation of the budget, thus negatively affecting the economy (Neelam 2014). As such, any increase in public spending in parallel with the increase in oil prices is unsustainable, as its consequences would be disastrous for the economy in the event of turmoil in the oil markets. Hence, countries that rely heavily on oil revenues should set a roadmap to avoid this risk (Köhler 2015; Swanepoel 2006). Kou et al. (2019) proved that systemic risks are closely related to machine learning methods, specifically for regulating financial markets. They also indicated the effectiveness of evaluating multiple-criteria decision-making models in clustering algorithm analysis, whose aim is to find solutions to financial risks.

From the perspective of sustainable development, the challenge of fluctuating oil prices could be met if countries start saving a large proportion of their oil revenues in periods of high oil prices (Nidhaleddine and Waël 2016). This situation would lead to the building of reserves to meet the expenditure during low oil prices rather than initiating a drastic fiscal cutback and austerity measures (Abeysinghe 2001). Such kneejerk reactive policies would curb the sustainable development process and cut back on consumer spending (Ajmi et al. 2015).

The focus thus shifted to understanding the potential and wealth of environmental resources of countries (Basnet and Upadhyaya 2015), with most countries seeking out ways of early prediction for financial crises and upheaval in the pricing of petroleum and non-petroleum wealth, especially oil prices (Brown and Yücel 2002). Kong and Wei (2017) established the impact of energy pricing for the development of financial infrastructure of a country and its significance on the economic environment and growth of the country. Further, the development of financial infrastructure for such countries is considered directly related to their ability of using petroleum resources and abiding by carbon emission norms (Iwedi et al. 2015). Oil-reliant countries must thus be able to exploit the non-petroleum sector, which is also referred to as "environmental wealth," as a heavy reliance on the oil sector can lead to economic risks and a weaker financial system (Korkmaz 2015). As Awan (2013) pointed out, the rational use of environmental wealth plays a vital role in achieving sustainable economic development. GDP is an appropriate indicator for analyzing the performance of growth in different countries worldwide (Jamil and Ahmed 2010). However, for oil-exporting countries, it is significantly affected by fluctuations in oil prices on the global market, unlike the rest of the world, where the GDP is affected by domestic prices (Oladosu 2009). In other words, the greater contribution of oil activities in an economy enhances the impact of crude oil prices on the nominal GDP (Nkomo 2006). 
Elliott (2008) showed that an environmentally sustainable stage is achieved with economic development. Castro (2004) also explained the effect of economic and environmental development on the sudden fluctuations in oil prices. Jimenez-Rodriguez and Sanchez (2005) explained the relationship between oil prices and the GDP, and found a non-linear relationship whose impact is greater in the case of increased oil prices than otherwise. Their findings also indicated an increase in oil prices would negatively affect the GDPs of oil-importing countries, whereas it has a positive impact on the GDPs of oil-exporting countries.

The study of Kim and Willett (2000) on the $\mathrm{G}^{-7}$ countries, Norway, and the Euro area as a whole found that the relationship between GDP and oil prices is negative; the authors used a non-linear model of the relationship between oil prices and real activity, which provides better performance than the linear model. Bouchaour and Al-Zeaud (2012) found that oil prices have no impact on the real GDP of Algeria in the short term. The study of Iwayemi and Fowowe (2011) on Nigeria found that the fluctuations in oil prices did not significantly affect most macroeconomic variables during 19852007, but their impact on the GDP was positive. Ibrahim et al. (2014) concluded that Nigeria's GDP was always increasing; meaning Nigerian economic growth did not suffer any decline during 1981-2012. Ito (2008) found that the fluctuations in oil prices contributed to the growth (or decline) of real GDP in Russia in the long term, while Bichler and Gaderer (2009) showed that sustainable development related to the environment is achieved by a combination of economic growth and political and social factors. Adams (2009) focused on solutions to environmental problems in terms of global expansion in production and sustainable development.

The Central Bank of Oman (2005-2016) showed that the oil sector in Oman contributes $45 \%$ to the GDP, while the strategic vision for 2020 (Vision 2020) suggests a reduction of this ratio to $22 \%$ by investing USD 106 billion over 5 years. It also proposes reducing the contribution of natural gas revenues to $2.4 \%$ of the GDP from the present 3.6\% (Central Bank of Oman 2015). Further, oil-exporting countries should be aware of the importance of using nominal and real GDP data in macroeconomic analyses. In light of the collapse of crude oil prices, the pressure on oil-producing countries is so high that most of them have started supporting non-oil activities and reducing the contribution of the oil industry to the national economy. According to Vision 2020, Oman aims to increase the size of its industrial base from $5 \%$ to $15 \%$ of the GDP by 2020 . Within the framework of the government's economic diversification program, the industrial base has been steadily expanding. As a result of the reduction in public expenditure and the economic slowdown of 2015, the value-added services of non-oil industrial activities grew by only $0.4 \%$ compared to $3.8 \%$ in 2014 .

There is a negative impact on consumption, investment, and employment when oil prices increase (Ajmi et al. 2015). The consumption is positively correlated with disposable income and investment through increased corporate costs, which may lead to increased uncertainty and the postponement of investment decisions (Köhler 2015). Considering the consumer price index (CPI), the rising oil prices are fueling a rise in domestic fuel prices, leading to a decline in household purchasing power and a slowdown in consumer spending (Lescaroux and Mignon 2008). This rise in oil prices is thus affecting the price index of products. Overall, the high energy price leads to lower productivity, which shifts to(i) the wage rate,(ii) prices of products and the rate of 
inflation, and (iii) subsequently reflects on net profits and the rate of investment (Jones et al. 2004; Lardic and Mignon 2006).

The economic resources available to a society are natural, physical, and human (Nidhaleddine and Waël 2016). The preservation of the environment and natural resources is no longer the work of enterprises to strengthen the balance of payment; rather, it has become legally binding in most countries (Iwedi et al. 2015). These improved decision-making models help reduce operating costs and improve financial and investment performance. Chao et al. (2019) noted that the behavior of abnormal returns can be mitigated through the use of trade-based money laundering methods combined with macro-prudential and micro-prudential regulation. This method has demonstrated a clear improvement in management efficiency, as well as intensive use in the financial market through the use of arbitrage cross-border capital flows. Further, Zhang et al. (2019) argued that group decision-making models are an important method of decision-making that affects the costs of several investment and financing processes.

According to Gomez-Lobo (2001), resource-rich countries do not have the advantage of consuming these resources themselves; rather, they should be used in resource-poor countries, and both should be committed to using these resources sustainably. The sustainable growth of real resources includes continuous reductions in energy, power, and natural resource consumption by improving efficiency, radically changing lifestyles, changing the patterns of consumption that threaten biodiversity, balancing development, and preserving the environment (Nidhaleddine and Waël 2016). Current generations must use natural resources in a manner that does not ignore or threaten the rights of future generations to the environment and future development (Samuel and Lionel 2013). Natural resources achieve the desired economic and social progress (Oladosu 2009). The energy issues are complex and challenging and they may take energy from non-renewable resources (coal, oil, and gas) or renewable resources (wood, sun, and water) (Abeysinghe 2001; Samuel and Lionel 2013).

National income accounts have long disregarded the role of nature in the production process (Ajmi et al. 2015). Therefore, when estimating value-added services or the output in the main sector, no value is added to the actual cost of natural resources that have been exploited and the waste of harmful products from factories, companies, and governments (Iwedi et al. 2015). Many costs are ignored, especially because of natural environmental pollution (Dasgupta and Maler 2000).

Therefore, there is increasing criticism of the macroeconomic indicators used in the system of national accounts (Cunado and De Gracia 2005). The absence of national accounting for some societies leads to conflicting information regarding organization, ultimately leading to the gradual loss of resources (Lane and Milesi 2007). Arrow et al. (2004) and Dasgupta (2001) focused on sustainable development, which is achieved when the assets' shadow prices of environmental wealth are stable in the economy.

Awan (2013) showed that, for developed countries, an effective utilization of environmental wealth results in the enhanced availability of natural resources for production of surplus goods and products, leading to export surplus (Ajmi et al. 2015). However,in emerging countries, this wealth is utilized to increase the capacities for the further exploitation and effective usage of environmental resources to achieve self-reliance and sustainable development (Cunado and De Gracia 2005). 
Economic indices indicate the progress and direction of growth of such countries (Abeysinghe 2001).

The economic slowdown and fall in petroleum prices also had a negative impact on the growth of Oman. Recent statistical reports of its Central Bank (2005-2016) indicated that the economy of Oman has shown signals of decline in terms of economic growth. In response to the recent economic crisis, the government initiated strict adherence to an austere fiscal policy initiative. Several development projects and infrastructure initiatives were delayed and, thus, the flow of money in the economy started to diminish. The government intensified fiscal measures to ensure sustainable economic growth that would increase spending and revenue (Kim and Willett 2000).

In this context, many countries have started developing their non-oil sector and extracting natural resources to boost their economic wealth (Jamil and Ahmed 2010). Additionally, laws have been enacted to regulate these resources and open them to the private sector to work together with governments to build financial institutions (Köhler 2015). One of the most important obstacles in the implementation of the environmental regulatory system is the cost of implementation of, in addition to the lack of qualified expertise and sufficient knowledge in, ISO 14001(Campos et al. 2016). Most countries focused on petroleum and non-petroleum activities need to determine the extent to which these activities affect the monetary structure, specifically the availability of bank credit, which is the engine of economic activity (Neelam 2014).

In this vein, Oman is concerned with the appropriate distribution of industrial, service, and financial activities in all of its economic sectors to achieve effective integration between sustainable development and the environment and to take advantage of them in an optimal manner. An in-depth analysis of the environment should be used in decision making (Abeysinghe 2001). This analysis would lead to addressing the quality of the environment and maintaining its integrity to obtain the best output and a good climatic behavior (Călămar et al. 2017).

Environmental wealth is considered the main pillar of economic activity in any country, effectively influencing its monetary policy and economic growth and development (Ajmi et al. 2015). The effective exploration and exploitation of environmental wealth brings surplus revenue that further strengthen the financial system of the country, specifically the availability of easy and cheap bank credit (Iwedi et al. 2015). The availability of bank credit acts as a catalyst for the development of the non-petroleum sector and enhances industrial activities (Neelam 2014). With the development of these sectors, the exploitation and optimal usage of environmental wealth is also enhanced and leads to an increase in the international trade and relations of the country (Samuel and Lionel 2013).

In our opinion, a correct balance between the development and conservation of the environment is the responsibility of present generations, who should not exploit the environment and natural resources as sole owners and rather understand and appreciate the rights of future generations. Any abuse and exploitation could lead to serious ramifications for future generations and would threaten their survival and the objective of achieving the desired economic and social progress.

Previous studies Ibrahim et al. (2014); Iwayemi and Fowowe (2011); (Oladosu 2009) demonstrate a linear relationship between oil prices and GDP. Additionally, economic and financial fluctuations positively affect petroleum-related activities. As such, an 
increase in the price of petroleum activities contributes positively to the exports of a country. The increase in capital spending works in parallel with the construction of the country's institutions and infrastructure, which would not be achieved without a strong source of income. Reducing the risk of low oil prices is achieved by building an emergency alternative plan for this potential change. All countries must maintain a reasonable financial budget for sustainable development activities, as well as flexible economic and financial policies that stimulate domestic and foreign investment. Furthermore, clean energy consumption and a friendly environment contributes significantly to stimulating non-oil activities and increasing foreign investment. Sustainable development can thus be achieved through a combination of social, economic, and environmental factors that affect the community positively. The high productivity of energy wealth then contributes to the well-being of the society, increases employment, reduces inflation, and increases investment.

As previously mentioned, most authors focus on oil policy as a petroleum activity and its relationship with certain economic and financial variables. For example, Lardic and Mignon (2008) referred to the role oil pricing policy in activating the economic industry, while Oladosu (2009) argued for reducing the dependence on the petroleum sector to enhance the economic performance of oil-dependent countries. Several previous studies, such as those of Ajmi et al. (2015), Calza et al. (2006), Jiménez et al. (2009), Köhler (2015), and Neelam (2014), discuss the generation of environmental wealth policies and sources of revenue. Several studies, such as those of Lardic and Mignon (2008), Gabor et al. (2017), Ibrahim et al. (2014), Brown and Yücel (2002), and Ferderer (1996), discussed the volatility of oil pricing policy and GDP or export revenues. Advanced technology is also a key variable in identifying energy sources and economic development (Oladosu 2009).

In short, most studies have not comparatively discussed petroleum and nonpetroleum policies. Furthermore, a financial development proxy in regard to bank credit has not been discussed as a dependent variable, as most studies have discussed economic growth proxies instead of financial growth in addition to the lack of such a study on Oman, which is a producer and exporter of oil. This study aims to overcome this previous research gap and apply an autoregressive distributed lag ARDL model to Oman for 1978-2017. This period is considered critical due to the occurrence of financial crises. Specifically, this study attempts to highlight non-oil activity, which many oil countries, including GCC countries, should focus on to enhance other sources of income and promote financial development to mitigate the impact of oil price changes on economic growth. However, at present, it is imperative to consider the diversification of investment tools, which the government of Oman began to implement by undertaking investment in industrial, service, and insurance activities.

The main contribution of this study is the focus on the following aspects. First, the literature review clarifies the concepts of petroleum and non-petroleum activities and financial development. Second, it analyses the statistically significant impact of petroleum and non-petroleum variables on the financial development in Oman. Third, it diagnoses whether petroleum or non-petroleum indicators have affected the financial development of Oman more strongly. Finally, it provides recommendations for risk mitigation for specific economic and financial indicators. 
The findings demonstrate that a long-term equation has been estimated, which illustrates that the agriculture and industry sectors have a negative and significant relationship with the credit bank in Oman; however, its oil and service sector GDP promotes financial development. Meanwhile, the short-term equation illustrates that the oil, agricultural, and service sectors have positive and significant effects on domestic credit. Our analysis also supports the fact that the government of the Sultanate of Oman has recently taken an interest in industrial projects to diversify its industry.

\section{Background}

The development of the economic and financial sector has become a necessity in many countries to achieve sustainable development goals. In this context, the Central Office of Statistics for Bank Credit was established in 1978 within the Central Bank of Oman. Banks and financial institutions must report data on borrowers. Having a strong credit information system is a requirement for a strong, stable, and sustainable market in any economy. Credit information reports save time and administrative costs for participating institutions and help them grant credit faster and at a rate appropriate to returns. Borrowers are also expected to become more committed to repaying their loans on time, knowing that the credit information would be shared and controlled by other institutions before granting new loans (Central Bank of Oman 2017).

Oman has recently participated to many agreements, especially the emergence of the 1992 Rio Conference on Environment and Development, which aims to accelerate sustainable development (Central Bank of Oman 2017). One of the outcomes of this conference was to reaffirm international cooperation and recognize the need to integrate the environment into development for sustainability. There, Oman presented measures on the implementation of a special agenda for sustainable development in various economic and financial sectors in light of environmental changes. Oman is vast country with a total land area of $309,500 \mathrm{~km}^{2}$, divided into 11 regions and 61 Wilayats (provinces). Oman's Vision 2020 national development plan ensures that each region develops economically, with different competitive advantages in terms of environmental wealth.

Oman has a large reserve of natural resources that has recently been opened for exploration and mining. With a population of around 2.5 million, the country has one of the highest literacy rates of 99.3\%in the GCC. It also has a large network of 1500 government schools from standard 1 to 12 and 30 higher education institutions, including universities. It is spending annually around USD4 billion on the development of its human resources (Ministry of Environment and Climate Affairs 2017). The Central Bank of Oman (2017) showed that, since 2011, the government of Oman has tried to increase attention to the needs of its citizens and played an important role in the development of the economic and financial sectors by creating leaders who contribute and own companies, there by developing the country.

The country's GDP increased from USD 256.3 million in 1970 to USD 79.66 billion in 2013.The infant mortality rate has significantly reduced as a result of the progress in the health sector. The level of the education sector has also improved, especially among females (Central Bank of Oman 2017). Moreover, Oman has ensured the development of the public sector effectively through its information and communication technology (ICT) strategy, as this initiative is important for achieving sustainable development and 
building trust between citizens and the government by providing citizens with effective, fast, and transparent governmental services and reducing bureaucracy in business transactions. Oman's vision is to transform the economy into a knowledge-based economy, and, therefore, special emphasis is being given to the development of human resources in terms of higher education, training, and skill development (Ministry of Environment and Climate Affairs 2017).

The banking sector is also important for industrial observers in terms of the degree of liquidity available to them, especially after the pressure of oil prices. The market of Oman is characterized by a high percentage of personal loans, which accounted for $40 \%$ of the total credit in 2015. The Central Bank of Oman encourages personal lending to be no more than $50 \%$ of the total credit portfolio of banks. At the same time, it encourages lending to companies, especially in the construction sector, for sustainable development and infrastructure construction (Central Bank of Oman 2017).

In 2017, however, the government's burden increased which led to reduced spending and banks having fewer opportunities to lend. The Central Bank of Oman 2017 has also encouraged credit lending to small- and medium-sized enterprises despite the high risks and low returns and has allocated $5 \%$ of the bank loan portfolio to the small- and medium-sized enterprise sector.

The government's e-Oman initiative has been highly successful in bringing all governmental and non-governmental essential services within the domain of e-services. All residents can easily avail these services. The application of such digital technology (also known as e-government services) has given the government of Oman the ability to communicate, interact, and transact more effectively with its residents (Central Bank of Oman 2017).

The government's entrepreneurship program also plays a vital role in the sustainable development of the country and helps in the creation of new ventures. This program has led to industry growth in a competitive manner among all domestic and international economic sectors, which has in turn led to the promotion of free work and creation of new jobs, as well as the introduction of new technologies to establish innovative products and services. Oman has already developed a draft Vision 2040, wherein the main objective is to achieve all-round growth and progress and the development of the non-petroleum sector for more sustainable development (Ministry of Environment and Climate Affairs 2017).

\section{Research methodology}

This study employs an empirical methodology and the data are sourced from the World Bank Indicators from 1978 to 2017.The time frame is 40 years, which is a limitation of the study because no data are available for the previous period.

\section{Main model}

This study applies the ARDL model proposed by Pesaran and Shin (1999) and subsequently modified by Pesaran et al. (2001) by introducing bounds testing. We use this method to estimate our model for several reasons. First, this statistical tool fits in small-size samples; whereas Johnson (1959) technique is meant for large-size samples to achieve sound results. Second, the ARDL model does not require variables to be 
integrated of the same order, meaning one could use this method even if there are mixed integrated variables $(I(0)$ and $I(1))$, but no second-order variables are included. Third, Nkoro and Uko (2016) noted that Pesaran et al. (2001) explained if the relationship is only long-term; the ARDL model would be able to differentiate between variables. This ARDL model thus assumes a small single reduction in equation exists for dependent and exogenous variables. Finally, the ARDL model is considered a linear transformation. This is to achieve error correction model (ECM) estimates, which allow merging short-term corrections with the long-term equilibrium while retaining longterm information.

The ARDL model includes long-term relationship between variables and is formulated according to Pesaran and Shin (1999) as follows:

$$
\begin{aligned}
\Delta D C_{t}= & C_{t}+\sum_{i_{1}=1}^{l_{1}} \alpha_{1_{i}} \Delta \operatorname{Agr}_{t-i_{1}}+\sum_{i_{2}=1}^{l_{2}} \alpha_{2_{i}} \text { AIndust } \operatorname{Int}_{t-i_{2}}+\sum_{i_{3}=1}^{l_{3}} \alpha_{3_{i}} \Delta O \operatorname{OIR}_{t-i_{3}} \\
& ++\beta_{2_{j}} \text { Agric }_{t-j}+\sum_{i_{3}=1}^{l_{3}} \alpha_{4_{i}} \Delta \operatorname{Serv}_{t-i_{4}}+\sum_{i_{4}=1}^{l_{4}} \alpha_{4_{i}} \Delta D C_{t-i_{4}} \\
& +\beta_{1_{j}} D C_{t-j} \beta_{3_{j}} \text { Industy }_{t-j}+\beta_{4_{j}} \text { OIR }_{t-j}+\beta_{5_{j}} \operatorname{Serv}_{t-j}+\varepsilon_{t},
\end{aligned}
$$

Where $\Delta$ is the difference operator and $\varepsilon_{t}$ is the error term (white disturbance). $D C_{t}$ is domestic credit to the private sector by banks (\% of GDP); this variable measures financial development. $C_{t}$ is a constant; $O I R_{t-i_{3}}$ is are oil rents (\% of GDP) as the petroleum proxy. Additionally, three variables measure the non-petroleum proxy as follows: Indust $_{t-i_{2}}$ is the industry (including construction) value-added (\% of GDP); Agric $_{t-j}$ is agriculture, forestry, and fishing value added (\% of GDP); and $\operatorname{Serv}_{t-j}$ is services value added (\% of GDP).

The $F$-statistic is calculated from the ordinary least square estimation of eq. (1) to detect the presence of co integration. The lagged level variables are equal to zero (i.e., $\beta_{1}=$ $\left.\beta_{2}=\beta_{3}=\beta_{4}=\beta_{5}=0\right)$ to verify the null hypothesis of no co integration. These variables are set against the alternative hypothesis that $\beta_{1} \neq \beta_{2} \neq \beta_{3} \neq \beta_{4} \neq \beta_{5} \neq 0$. The lower bound assumes variables are $I(0)$,whereas the upper bound assumes $I(1)$ variables. These two asymptotic values come from critical value bounds testing. If the computed $F$-statistic is greater than the upper critical value bound, the null hypothesis of no co integration is rejected. As per eq. (1), the ARDL-based ECM required for the short-run result is formulated as follows:

$$
\begin{aligned}
\Delta D C= & C_{t}+\sum_{1}^{1} \alpha_{1} \Delta \text { Agri }_{t-1}+\sum_{1}^{2} \alpha_{2} \Delta \text { Aindust }_{t-2}+\sum_{1}^{3} \alpha_{3} \Delta \text { OIR }_{t-3} \\
& +\sum_{1}^{4} \alpha_{4} \Delta \operatorname{Serv}_{t-4}+\sum_{1}^{4} \alpha_{1} \Delta D C_{t-4}+\delta E C T_{t-1}+\varepsilon_{t} .
\end{aligned}
$$

Alphas $(\alpha)$ are short-run coefficients and $\delta$ is the extent of disequilibrium correction (i.e., the speed of adjustment).

Many studies, such as those of Arrow et al. (2004), Dasgupta (2001), Dasgupta and Maler (2000),Jones et al. (2004), and Lardic and Mignon (2006), used different methodologies to test the impact of environmental wealth on financial and economic development. We can define these variables using the World Development Indicators (2017) as follows: services value added (\% of GDP). The index refers to services that include wholesale, retail, transport, finance, and all professional government services, such as education, health, and real estate. It also includes all fees for banking, imports, and all intermediate inputs. Oil rents (\% of GDP) refer to the value of raw feed production at 
the world price, minus production costs. Industry (including construction) value added (\% of GDP), includes the net value added in manufacturing and mining, including water, electricity, and construction. Domestic credit to the private sector by banks (\% of GDP) is the financial resource provided by banks to the private sector in the country through depository companies and includes the operations of loans, securities, commercial credit, and all accounts receivable. Agriculture, forestry, and fishing value added (\% of GDP) includes value added after subtracting all intermediate inputs and includes all economic activities, namely fishing, forestry, and agriculture for all crops and animal production.

There are many reasons for selecting these variables in most emerging countries, including Oman. Domestic credit to the private sector by banks (\% of GDP) is the cornerstone of economic and financial development. Banks play an important role as money suppliers. The banking system facilitates domestic and international trade. Much of the trade is conducted by credit. The importance of credit in business cannot be denied because money supply is the lifeblood of borrowers' economy. There are exporters who meet the capital requirements of a company, where commercial banks take money savings and borrow them to both individuals and businesses. Credit allows purchases before the ability to pay to meet needs in various economic and financial sectors. Oil rents (\% of GDP) were also chosen as a major indicator of petroleum activities in Oman, mainly for the formation of state revenues, institution building, and infrastructure. After the financial crisis of 2008, to revitalize the non-petroleum proxy, this study focused on three variables: industry (including construction) value added (\% of GDP); agriculture, forestry, and fishing value added (\% of GDP); and services value added (\% of GDP), according to the classification of the Central Bank of Oman (2017).

\section{Empirical results and discussion}

Unit root tests: preliminary testing

We check for spurious regression by the properties of the time series. This study applies the unit root tests: Dickey-Fuller, extended Dickey-Fuller, and Phillips-Perron. The critical point is $5 \%$, with $\mathrm{H}_{0}$ referring to the null hypothesis of non-stationarity. We can select a suitable model for estimation by testing the unit root of the variables used. Table 1 shows the results of the stationary test. It shows that all variables have a unit root at levels, except OIR, for which it the null hypothesis is rejected. Therefore, this variable is integrated of order zero $(I(0))$. After taking the first difference between the remaining regressors, the null hypothesis was rejected, which means these variables were integrated at the first difference $I(1)$. The variables under consideration have a mixed order of integration $(I(0)$ and $I(1))$, while none of the variables were integrated of the second order $I$ (2). Once all variables were integrated at different orders, the ARDL model proved the most appropriate.

To test for the existence of a long-run relationship between domestic credit in Oman and sector level GDPs, the ARDL model was estimated. Before estimating the ARDL model, the appropriate lags were tested first. E-Views 10gives the ARDL model automatically. We adopted the Akaike information criterion (AIC) and determine the best 20 models as per the AIC. The ARDL model $(4,4,4,2$, and 4) corresponds to the smallest AIC value for Oman (Fig. 1). 
Table 1 Stationarity tests: unit root tests

\begin{tabular}{llllll}
\hline Variables & ADF & $P$-value (Decision) & PP & $P$-value (Decision) & Decision \\
\hline Level & & & & & \\
DC. & 0.750191 & 0.9918 & 0.513399 & 0.985 & Non-stationary \\
OIR. & -2.99694 & 0.044 & -2.61958 & 0.0977 & stationary I(0) \\
AGRI. & -1.64855 & 0.4488 & -1.72099 & 0.4131 & Non-stationary \\
SERVE. & -1.99213 & 0.289 & -2.16291 & 0.2225 & Non-stationary \\
INDUST. & -1.83911 & 0.3567 & -1.84986 & 0.3517 & Non-stationary \\
First Differences & & & & & \\
DC. & -4.71035 & 0.0005 & -4.60446 & 0.0007 (stationary) & stationary I(1) \\
OIR. & - & - & - & - & \\
AGRI. & -5.2516 & 0.0001 & -5.24289 & 0.0001 & stationary I(1) \\
SERVE. & -5.97157 & 0.0000 & -5.98874 & 0.0000 & stationary I(1) \\
INDUST. & -6.47528 & 0.0000 & -6.48002 & 0.0000 & stationary I(1) \\
\hline Source author's work based on the Outcome of Eviws vion 10 & &
\end{tabular}

After choosing the appropriate lags for the ARDL model, it is important to prove whether there exists a long-run relationship between the variables. To do so, we perform bounds testing. The asymptotic distribution of the joint F-statistic refers to bounds testing, which is non-standard under the null hypothesis of no co integration.

We also need to examine whether the variables are integrated or not. To achieve this, we must compare the $F$-statistic and the $I(0)$ and $I(1)$ bounds (Pesaran and Shin 1999). Table 2 shows that the $F$-statistic is greater than $I$ (1) in long-term relations. It also reports that co integration does not exist; this happens when the value is less than

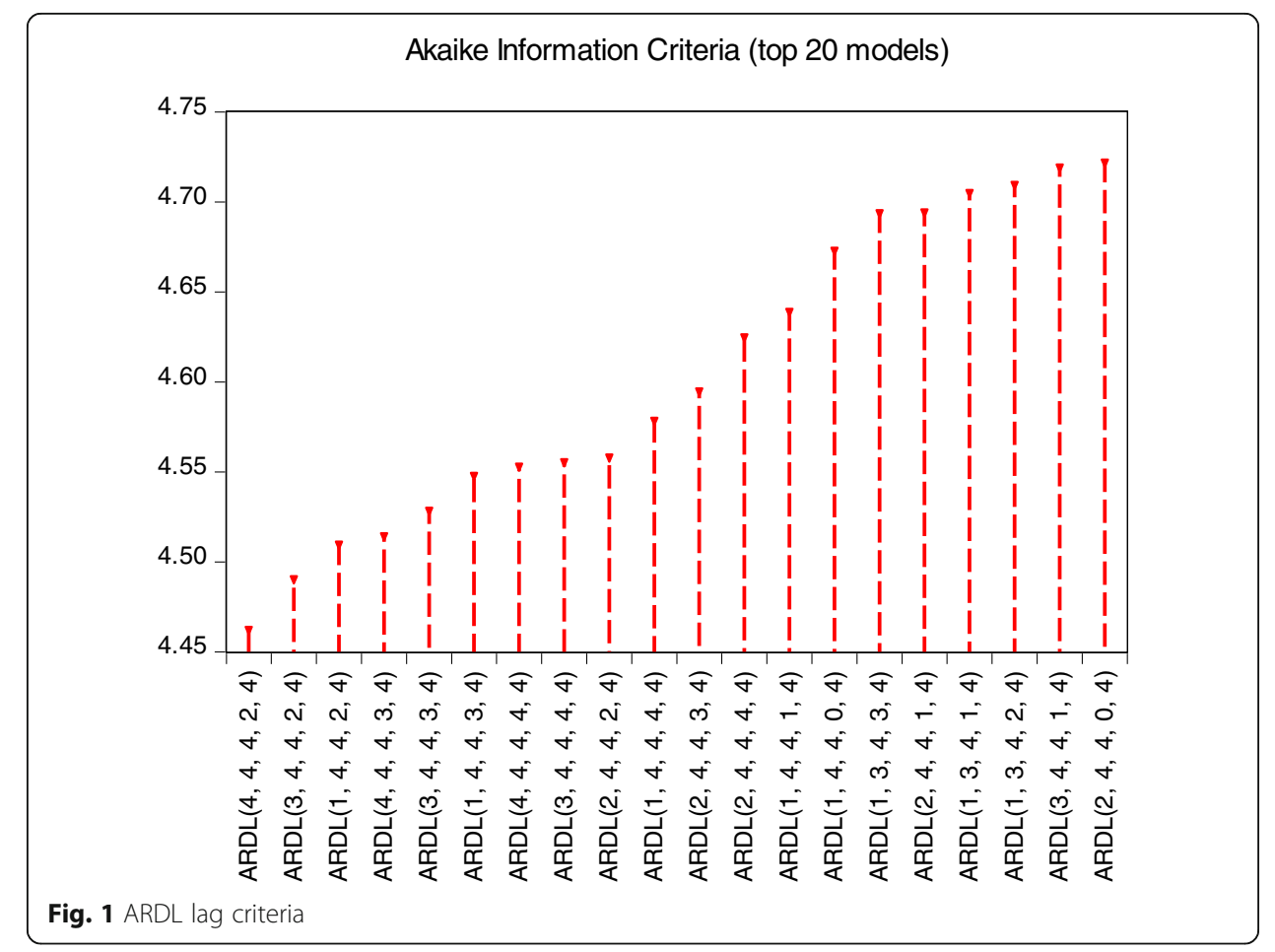


Table 2 Bound tests for co integration: F-test and t-test

\begin{tabular}{lllll}
\hline F-Bounds Test Null Hypothesis: No levels relationship & & \\
Test Statistic & Value & Levels of Significance. & Upper I(0) & Lower I(1) \\
F-statistic & 6.963107 & $10 \%$ & 2.2 & 3.09 \\
k & 4 & $5 \%$ & 2.56 & 3.49 \\
& $2.50 \%$ & 2.88 & 3.87 \\
& $1 \%$ & 3.29 & 4.37 \\
t-Bounds Test Null Hypothesis: No levels relationship & Sig. & & \\
Test Statistic & $10 \%$ & $1(0)$ & I(1) \\
t-statistic & Value & $5 \%$ & -2.57 & -3.66 \\
& -6.53647 & $2.50 \%$ & -2.86 & -3.99 \\
& $1 \%$ & -3.13 & -4.26 \\
\hline
\end{tabular}

Source: author's work based on the Outcome of E-views version.10

$I(0)$ and when the $F$-statistic calculated is found between the two bounds levels determined by the $I(0)$ and $I(1)$ values, no decision can be made.

Table 2 shows there exists a long-term relationship between domestic credit, agricultural, industrial, oil, and service activities. We compare the bounds testing results of the F-statistic model with the Pesaran critical values of $1.0 \%, 2.5 \%, 5.0 \%$, and $10.0 \%$. The $F$-statistic is greater than the critical value at all levels of significance. The lower bound value is 2.56 , whereas the upper bound value is 3.49 . This is an example of the model with a restricted constant Pesaran Table. A long-term relationship exists for the variables in this study. The $F$-statistic for the estimated model is 6.963 and is higher than the upper bound level of our model. Additionally, the existence of co integration by performing $t$-bounds testing shows robustness. The null hypothesis, namely no level relationship, is rejected at all levels of significance in the $t$-bounds testing (see Table 2).

\section{Long-run relationship: ARDL estimates}

Since there exists co integration between variables, we can estimate long-run relationships. The long-term equation is estimated, as reported in Table 3. Table 3 illustrates that the agriculture and industry GDP has a negative and significant relationship with domestic credit (financial development). The empirical results show that an increase in agricultural and industrial activities by $1 \%$ leads to a $5 \%$ and $3 \%$ decrease in financial development, respectively. This result is consistent with the findings of Arrow et al. (2012), who concluded that many other factors such as technological change, natural

Table 3 Long-run relationship: ARDL estimates

\begin{tabular}{lllll}
\hline Ind. Variables & Coefficient & Std. Error & t-Statistic & Prob. \\
\hline AGR. & -4.85 & 10.27 & -3.98 & 0.00 \\
INDUST. & -3.19 & 1.19 & -2.67 & 0.02 \\
OIR. & 4.25 & 1.87 & 2.27 & 0.04 \\
SERVE. & 1.38 & 0.59 & 2.34 & 0.04 \\
C & 101.59 & 43.22 & 2.35 & 0.04 \\
\hline Source: author's work based on the Outcome of E-views version 10 & &
\end{tabular}

Source: author's work based on the Outcome of E-views version.10 
capital, and health capital contribute to and affect the financial growth of major economies. However, Awan (2013) and Elliott (2008) pointed out that environmental wealth plays a vital role unsustainable economic development in different countries. Bouchaour and Al-Zeaud (2012) found no impact of oil prices and international power on real GDP, while the cooperation of different countries in the world based on international standards level can enhance the GDP of these countries (Barrett and Graddy 2000). However, Bichler and Gaderer (2009) showed that political and social factors work together and have an effect on the GDP. Our results also differ from those of Iwayemi and Fowowe (2011), who found that fluctuations in oil prices did not significantly affect most of the macroeconomic variables.

However, oil and service sector GDPs promote financial development. The positive impact of oil activities is greater than that of the service sector. Domestic credit increases by $4.25 \%$ when oil GDP increases by $1 \%$, while an increase in the service sector in Oman leads to a $1.38 \%$ improvement in financial development. The increase of banking activities in different countries often comes from growth in petroleum industries, as the welfare of communities and increased consumption creates more investment. The positive image of petroleum activities results from their integration with non-petroleum activities.

Using this method, the government is exposed global fluctuations in oil prices, thus imposing appropriate policies and facilitating banking away from petroleum and nonpetroleum activities in the industrial and service sectors in cooperation with the Central Bank. This highlights the need to pay attention to non-petroleum activities, especially in relation to financial crises and rapid changes in oil and gas prices globally and nondependence on petroleum activities for revenue and infrastructure building.

\section{Short-run relationship: ECM estimates}

After estimating the long-run equation, this section estimates the short-run relationship between the variables in our study to calculate the speed of adjustment. To do so, the ECM-ARDL model is estimated. Table 4 reports the results of the short-run relationship.

The model's error correction term (ECT) is stable when achieved by two conditions, as suggested by Pahlavani et al. (2005), that is, this relation is negative and statistically significant. ECT refers to the long-term balance through speed adjustment with one shock in the model. Table 4 shows ECT $(-1)$ is negative and statistically significant at the $1 \%$ significance level. It also shows that any previous period shock in this model would be adjusted in the run equilibrium with a speed of $33.2 \%$.

Form Table 4 that lagged domestic credit has a significant and positive effect on financial development. Specifically, 2 years' lagged domestic credit (DCt-2) increases the current domestic credit by about 3.2\%.Regardingthe impact of oil and service sectors, Table 4 shows that both sectors have positive and significant effects on domestic credit. However, this effect is smaller than the long-run effect. Their positivity ranges between 0.15 and 0.67 , which is smaller than 4.25 and 1.38 in the long run.

Interestingly, agricultural activities have a significant effect on financial development. In the short-term, any increase in agricultural GDP by $1 \%$ causes an increase in domestic credit by more than $1 \%$. This explains the government's dependence on the service 
Table 4 Short-run relationship ARDL model $(4,4,4,2$, 4)

\begin{tabular}{lllll}
\hline Variable & Coefficient & Std. Error & t-Statistic & Prob. \\
\hline D (DC(-1)) & 0.0004 & 0.1275 & 0.0030 & 0.9977 \\
D (DC(-2)) & 0.3296 & 0.1220 & 2.7021 & 0.0181 \\
D (DC(-3)) & 0.2271 & 0.1335 & 1.7018 & 0.1126 \\
D (AGRI) & 6.4167 & 1.6606 & 3.8641 & 0.002 \\
D (AGRI(-1)) & 1.8984 & 2.7447 & 4.6994 & 0.0004 \\
D (AGRI(-2)) & 1.8656 & 2.4957 & 4.7543 & 0.0004 \\
D (AGRI(-3)) & 7.3303 & 2.2973 & 3.1909 & 0.0071 \\
D (INDUST) & -0.4742 & 0.2097 & -2.2609 & 0.0416 \\
D (INDUST(-1)) & -0.1112 & 0.1824 & -0.6096 & 0.5526 \\
D (INDUST(-2)) & 0.0288 & 0.1624 & 0.1775 & 0.8618 \\
D (INDUST(-3)) & 0.1317 & 4.3333 & 0.0008 \\
D (OIR) & 0.5707 & 0.1395 & 1.1453 & 0.2727 \\
D (OIR(-1)) & 0.1597 & 0.1626 & -4.1662 & 0.0011 \\
D (SERVE) & 0.6776 & 0.0913 & 3.4445 & 0.0044 \\
D (SERVE(-1)) & 0.3144 & 0.1111 & -2.8469 & 0.0137 \\
D (SERV(-2)) & 0.3162 & 0.1053 & 2.1387 & 0.052 \\
D (SERVE(-3)) & 0.2251 & 0.1077 & 4.4087 & 0.0007 \\
(ECT-1) & 0.4748 & 0.0437 & -7.6057 & 0.000 \\
Adjusted R-squared & -0.3324 & & & \\
Durbin-Watson stat & 0.894223 & & & \\
\hline Source:athors work bas & 2.541182 & 0.167 &
\end{tabular}

Source: author's work based on the Outcome of E-views version.10

sector for non-petroleum activities more than the agricultural, fishing, and industrial sectors. It also explains why banks are promoting bank credit by increasingly funding contracts related to non-petroleum activities in the short run, especially in agriculture and fishing, thus contributing to an increase in GDP and shielding the economy from potential risks triggered by fluctuations in petroleum activities.

The results of this study are consistent with those of Gomez-Lobo (2001) in that the consumption index supports the sustainability process, but it is shared between rich and poor countries. The CPI is increasing oil prices in the short run and fueling a rise in domestic fuel prices, leading to a decline in household purchasing power and a slowdown in consumer spending (Lescaroux and Mignon 2008). Consumption is positively correlated with disposable income and investment through increased corporate costs, which may lead to an increase in uncertainty, therebypostponing investment decisions (Köhler 2015). Consumption is also affected by its positive relationship with disposable income and investment through increased corporate costs (Gones et al. 2004; Lardic and Mignon 2006). Intergenerational wellbeing (Dasgupta and Maler 2000) is the main factor to increase the attention paidtoCPI; this supports our results. National income accounts have long disregarded the role of nature in production (Ajmi et al. 2015). The complexities of renewable and non-renewable energy resources indirectly affect financial development (Abeysinghe 2001; Samuel and Lionel 2013). As such, petroleum and nonpetroleum activities contribute positively to the impact on domestic credit in an integrated and harmonious manner. 
The integration of economic activities is a significant effect, as per Arrow et al. (2004) and Dasgupta (2001) among others. This integration can achieve sustainable development by determining the environmental wealth of each country. Therefore, there exists increasing criticism of the macroeconomic indicators used in the system of national accounts (Cunado and De Gracia 2005).

As noted in the statistical reports of Oman, there has been a general decline in economic performance over the past 5 years, but the government has been taking concrete measures to rectify this decline. The world price of oil is the main reason, meaning the government is now trying to compensate for the shortfall in revenue from economic activities in the industrial or service sectors. The Central Bank of Oman (2017) indicates that national savings decreased by $40 \%$ during 2015 compared with the previous year, at a time when the country was witnessing a sharp decline in the value of exports of goods and services. Specifically, the national savings amounted to OMR 5 billion in 2015 compared to OMR 9 billion in 2014, after deducting the value of the final consumption of gross national income. The GDP per capita declined by 17\%, to OMR 6.4 thousand in 2015 compared to OMR 7.8 thousand in the previous year. The GDP per capita declined by $15 \%$ to OMR 6.2 thousand at the end of last year, compared to OMR 7.4 thousand at the end of 2014. According to these data, the GDP declined by $13.8 \%$ in 2015, reaching OMR 26.8 billion. The net exports of goods and services were worth OMR961 million, being down to $86.5 \%$ the value of 2014, with net exports of about OMR7.1 billion.

\section{Robustness checks of ARDL results: diagnostic tests}

Table 5 shows that the ARDL model is considered to be significant at $1 \%$ level and is therefore suitable for the proposed model. The success of all diagnostic tests against serial correlation, heteroscedasticity (the White heteroskedasticity test), and normality of errors (the Jarque-Bera test) are the lead to pass the ARDL model. Additionally, the Ramsey RESET test confirms that the model fits very well (Fig. 2).

This study has confirmed a long-term relationship through the application of the CUSUM test to predict this relation. This test is performed by recalculating the regression coefficients and associated residual values. Figures 3 and 4, based on the ARDL estimations, show the residual values as solid lines and the levels of confidence as dotted

Table 5 Robustness check: Diagnostic tests

\begin{tabular}{|c|c|c|c|c|c|}
\hline \multirow{2}{*}{$\begin{array}{l}\text { Normality test } \\
\text { Serial correlation test }\end{array}$} & \multicolumn{4}{|c|}{$\begin{array}{l}\text { J-B test Statistic (probability value) } \\
\text { Ho: Residuals are normal }\end{array}$} & $1.29(0.524)$ \\
\hline & $\begin{array}{l}F(2,11) 0.1= \\
\text { Chi-Square }\end{array}$ & & & & $\begin{array}{l}0.1335 \\
0.40\end{array}$ \\
\hline Heteroscedasticity test & $\begin{array}{l}\text { Breusch-G } \\
\text { F(2,11) } \\
\text { Chi-Square }\end{array}$ & $y$ test & & & $\begin{array}{l}0.1291 \\
0.2022\end{array}$ \\
\hline \multirow[t]{2}{*}{ Ramsey RESET test for misspecification } & t-statistic & 0.064002 & 12 & 0.9500 & \\
\hline & F-statistic & 0.004096 & $(1,12)$ & 0.9500 & \\
\hline Stability tests & \multicolumn{4}{|c|}{$\begin{array}{l}\text { CUSUM } \\
\text { CUSUM Square }\end{array}$} & $\begin{array}{l}\text { Stable } \\
\text { Stable }\end{array}$ \\
\hline
\end{tabular}

Source: author's work based on the Outcome of E-views version.10 


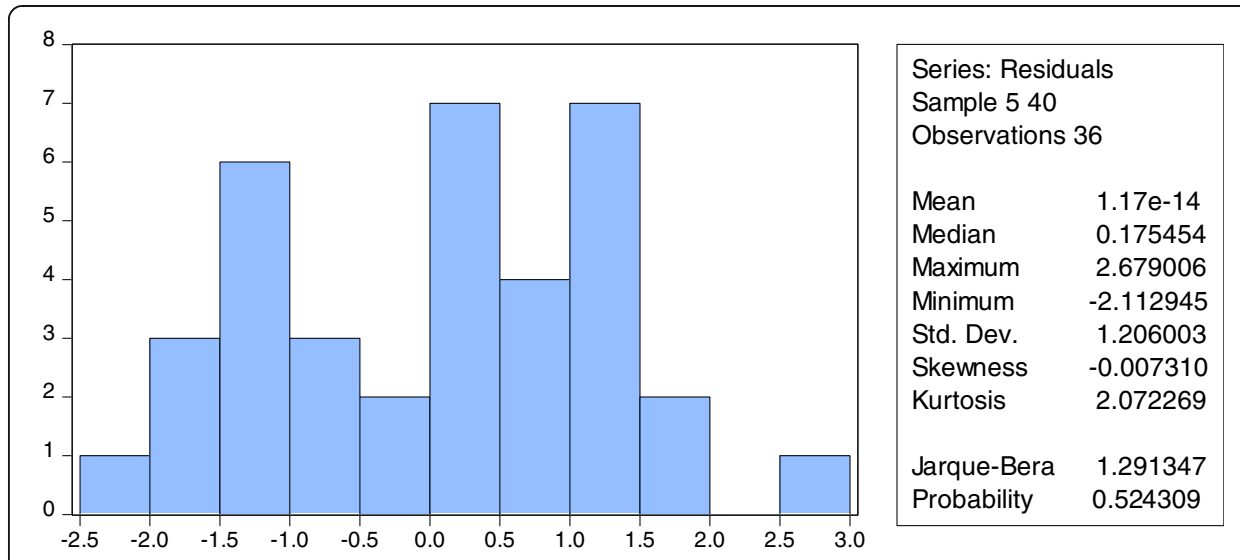

Fig. 2 Normality test of the ARDL model

lines. These figures also show the stability of the ARDL model because residual values are all between the confidence lines.

\section{Conclusions and policy implications}

The environmental wealth comprising all natural resources in any country is the main engine of growth for the economy, and countries need to preserve this wealth and use it judiciously, with the intent of optimizing their usage for economic growth and prosperity.

The aim of this study is to analyze the impact of the petroleum proxy of oil rents (\% of GDP) and the non-petroleum proxy of industry (including construction) value added (\% of GDP); agriculture, forestry, and fishing value added (\% of GDP); and services value added (\% of GDP) to show the effect on financial development, which is measured by domestic credit to the private sector by banks (\% of GDP). This study applies the ARDL model in Oman for 1978-2017. The long-term equation is estimated, which illustrates that agriculture and industry have a negative and significant relationship with bank credit in Oman. The results indicate that the agriculture and industry sectors do

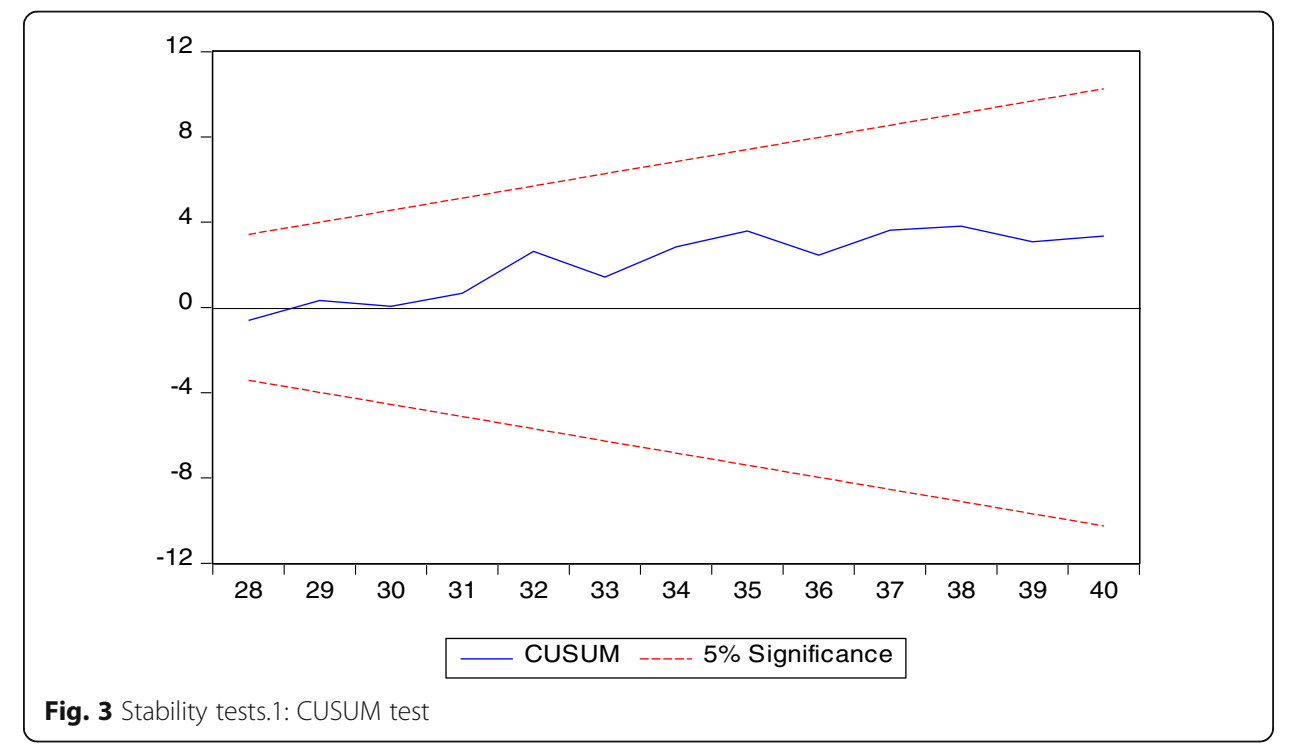




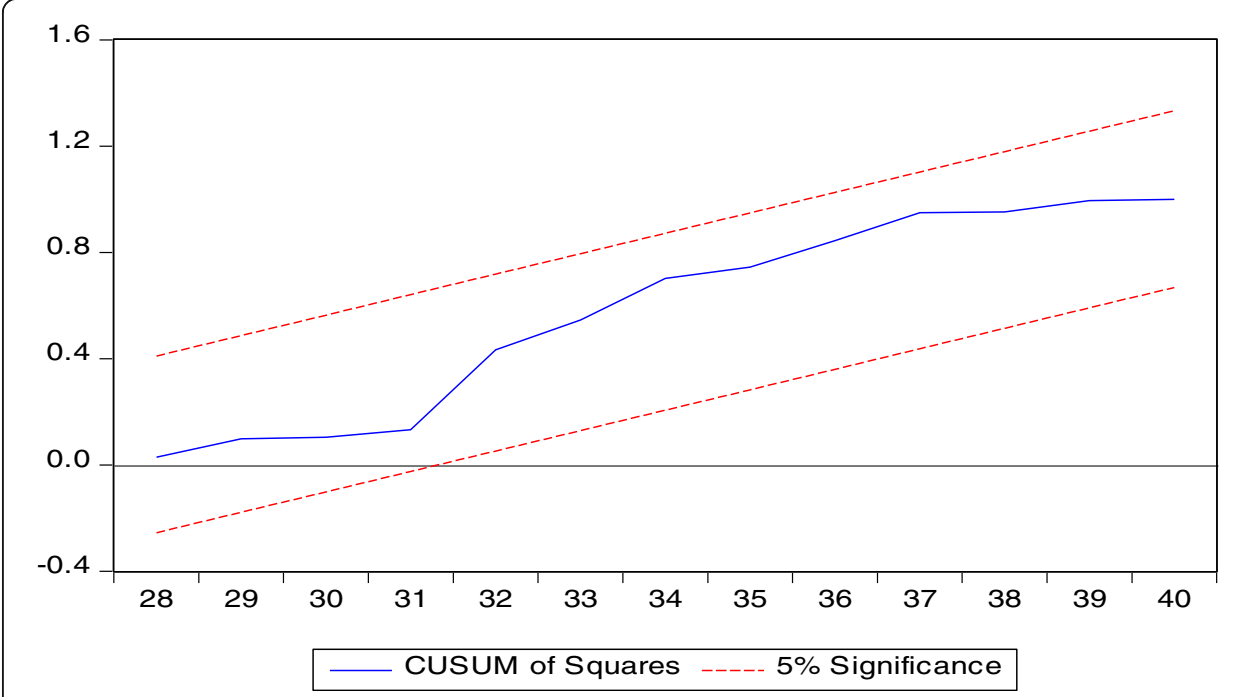

Fig. 4 Stability tests.2: CUSUM Square test

not rely mainly on bank credit to finance operations. It is still considered the second sector in the country economy. However, the government in the Sultanate of Oman has recently taken an interest in industrial projects, primarily to diversify the industry.

The empirical results showed that an increase in agricultural and industrial activities by $1 \%$ leads to a $5 \%$ and $3 \%$ decrease in the financial development of Oman's economy, respectively. These results indicate the agriculture sector has recently been trying to promote sustainable development. To achieve this goal, the government has developed programs for the advancement of the agricultural sector and the introduction of advanced production techniques with a focus on service quality and a competitive advantage; however, this has not been sufficient for promoting financial development at the national level.

The government has also encouraged private companies to invest in agricultural projects, while also becoming increasingly interested in the development of the industrial sector, the results indicating its improved ranking in terms of the promotion of financial development. Oman began to feel the need to diversify the industry after the global financial crisis of 2007, which affected oil prices (considered main revenue) and led to the need to further promote the industrial sector. Recently, the government has started to develop the economy, inspired by the Rafid Fund, which was established in 2014 to finance industrial projects, resulting in the financing of nearly 220 industrial projects by the end of 2018.

However, the oil GDP and service sectors also promote financial development. In fact, the positive impact of oil activities on financial development is greater than that of the service sector. Domestic credit increases by $4.25 \%$ when oil GDP increases by $1 \%$, while an increase in the service sector has led to a $1.38 \%$ improvement in financial development. These results prove that energy price instability has a significant impact on economic environment, as also found by Gabor et al. (2017), in that energy prices significantly impact the preservation of other energy sources.

The results also indicate that oil is the main income source of Oman, contributing positively and significantly to its financial development. They thus also highlight its 
dependence on oil for financing its operations related to bank credit, since the service and energy sectors have recently become more active despite the fluctuations in oil prices and the negative impact of the financial crisis of 2007. Moreover, the oil sector of Oman is closely linked to the financial sector and considered the main driving force behind investment and job creation. In recent years, the government of Oman developed the service sector to strengthen the oil sector through the promotion of non-oil revenue sources, such as education, health, housing, social welfare, and basic and strategic projects. It is still strategizing in regard to revenue distribution as a hedge for the decline in oil prices, despite a marked improvement the economy in 2018 compared to the previous 3 years.

The short-term equation illustrates that lagged domestic credit has a significant and positive effect on financial development. The results show that 2 years' lagged domestic credit (DCt-2) increases the current domestic credit by about 3.2\%. Both the oil and service sectors have positive and significant effects on domestic credit. However, this effect is smaller than the long-run effect. Their impact ranges between 0.15 and 0.67 , which is smaller than 4.25 and 1.38 in the long run. Interestingly, agricultural activities have a significant effect on financial development. In the short-term, an increase in agriculture GDP by $1 \%$ causes an increase in domestic credit by more than $1 \%$.The results indicate that the Oman government has prioritized financial sustainability and increasing its efficiency in spending to achieve certain economic goals related to development and investment on both the domestic and foreign levels. Therefore, it is evident that the integration of all economic sectors is essential for financial sustainability in Oman and, thus, this is what the government currently seeks through delays in determining the state's budget.

The results recommend that the government imposes a fiscal policy in a balanced manner to maintain financial growth and domestic demand, as well as improve the liquidity of the banking sector given the higher oil prices and increased global business, launch important structural reforms, and improve trade relations. This would in turn support medium- and long-term sustainable economic growth.

The government has also sought to reduce its dependence on the oil sector, while aspiring to revive non-oil growth through supporting small- and medium-sized enterprises and foreign investment. The availability of data is a major limitation and, in our case, that data are only from Oman. Although Oman is representative of the GCC region in terms of economic model and policy, geographical environment, and climate, it differs in terms of wealth and the process of sustainable development from other GCC countries. Future studies can consider the geographical distribution of countries and generalize the results to the GCC oil-exporting countries. Additionally, different economic and financial dimensions can be applied in addition to the social and environmental dimension of petroleum and non-petroleum activities, which are essential elements in the sustainable development process.

Acknowledgments

The authors would like to thank the editor and anonymous referees for their valuable comments and suggestions to improve the quality of this paper. 


\section{Funding}

We do not receive any financial assistance from any agency.

\section{Availability of data and materials}

Source of data sets are available in World Bank Indicators from 1978 to 2017, at the link https://data.worldbank.org/

\section{Competing interests}

The authors declare that they have no competing interests.

\section{Author details}

'Department of Finance and Economics, College of Commerce and Business Administration, Dhofar University, P.O. Box: 2509, 211 Salalah, Sultanate of Oman. ${ }^{2}$ Department of Accounting, College of Commerce and Business Administration, Dhofar University, P.O. Box: 2509, 211 Salalah, Oman. ${ }^{3}$ Department of Finance and Economics, College of Commerce and Business Administration, Dhofar University, P.O. Box: 2509, 211 Salalah, Oman.

Received: 24 October 2018 Accepted: 11 February 2020

Published online: 20 February 2020

\section{References}

Abeysinghe T (2001) Estimation of direct and indirect impact of oil price on growth. Econ Lett 73(2):147-153

Adams WM (2009) Green development: environment and sustainability in a developing world, 3rd edn. Routledge, USA

Ajmi A, Gupta R, Babalos V, Hefer R (2015) Oil price and consumer price nexus in South Africa revisited: a novel asymmetric causality approach. Energy Explor Exploit 33(1):63-74

Arrow K, Dasgupta P, Goulder L, Mumford K, Oleson K (2012) Sustainability and the measurement of wealth. Environ Dev Econ 17:317-353 , Cambridge University Press 2012. https://doi.org/10.1017/S1355770X12000137

Arrow K, Dasgupta P, Goulder L, Daily G, Ehrlich PR, Heal GM, Levin S, Mäler K-G, Schneider S, Starrett D, Walker B (2004) Are we consuming too much? J Econ Perspect 18(1):147-172

Awan A (2013) Relationship between environment and sustainable economic development: a theoretical approach to environmental problems. Int J Asian Soc Sci 3(3):741-761

Barrett S, Graddy K (2000) Freedom, growth, and the environment. Environ Dev Econ 5:433-456

Basnet HC, Upadhyaya KP (2015) Impact of oil price shocks on output, inflation and the real exchange rate: evidence from selected ASEAN countries. Appl Econ 47(29):3078-3091

Bichler R, Gaderer E (2009) Towards criteria of sustainability and social meaningfulness in development: critical reflections on modernization theoretical thinking and its implications for ICTs in development. J Glob Sustainable Inf Soc 7(2):408-414

Bouchaour C, Al-Zeaud H (2012) Oil price distortion and their impact on Algerian macroeconomic. Int J Bus Manag 7(18):99-114

Brown SPA, Yücel MK (2002) Energy prices and aggregate economic activity: an interpretative survey. Q Rev Econ Finance 42: 193-208

Călămar A, Găman G, Pupăzan D, Toth L, Kovacs I (2017) Analysis of environmental components by monitoring gas concentration in the environment. Environ Eng Manag J 16(6):1249-1256

Calza A, Manrique M, Sousa J (2006) Credit in the euro area: an empirical investigation using aggregate data. Q Rev Econ Finance 46(2):211-226 https://doi.org/10.1016/j.qref.2005.02.001

Campos L, Trierweiller A, Carvalho D, Šelih J (2016) Environmental management systems in the construction industry : a review. Environ Eng Manag J 15(2):453-460

Castro C (2004) Sustainable development: mainstream and critical perspectives. Organ Environ 17(2):195-225

Central Bank of Oman (2015) Annual Statistical Bulletin. Retrieved From https://cbo.gov.om/ (Accessed: June 2019).

Central Bank of Oman (2017) Annual Statistical Bulletin. Retrieved From http://www.cbooman.org/ (Accessed: June 2019)

Chao X, Kou G, Peng Y, Alsaadi F (2019) Behavior monitoring methods for trade-based money laundering integrating macro and micro Prudential regulation: a case from China. Technol Econ Dev Econ. Article in press https://doi.org/10.3846/tede. 2019.9383

Chen $\mathrm{H}$, Kang H, Lee A (2017) A decision making model for selecting environmental I management system ( EMS) project contractor. Environ Eng Manag J 16(7):1583-1594

Cunado J, De Gracia FP (2005) Oil prices, economic activity and inflation: evidence for some Asian countries. Time Horiz Rev Econ Finance 45(1):65-83

Dasgupta P (2001) Human well-being and the natural environment. Oxford University Press, Oxford

Dasgupta P, Maler K-G (2000) Net national product, wealth, and social wellbeing. Environ Dev Econ 5(1):69-93

Elliott J (2008) An introduction to sustainable development, 3rd edn. Routledge, USA

Ferderer JP (1996) Oil Price volatility and the macro economy: a solution to the asymmetry puzzle. J Macroecon 18:1-16

Gabor T, Dan V, Badila I, Tiuc A, Sur I (2017) Improving the energy efficiency of residential building by using a drain water heat recovery system. Environ Eng Manage J 16(7):1631-1636

Gomez-Lobo A (2001) SustainabledevelopmentAnd natural resourceaccounting in asmall open economy. Estud de Econ 28(2):203-216

Ibrahim A, Ayodele A, Hakeem M, Yinka A (2014) Oil Price shocks and Nigerian economic growth. Eur Sci J 10(19):375-391

Ito K (2008) Oil price and the Russian economy: a VEC model approach. Int Res J Financ Econ 17:68-74

Iwayemi A, Fowowe B (2011) Impact of oil price shocks on selected macroeconomic variables in Nigeria. Energy Policy 39(2): 603-612

Iwedi M, Igbanibo DS, Onuegbu O (2015) Bank domestic credits and economic growth nexus in Nigeria. Int J Finance Account 4(5):236-244

Jamil F, Ahmed P (2010) The relationship between electricity consumption, electricity prices and GDP in Pakistan. Energy Policy 38:6016-6025 
Jiménez G, Ongena S, Peydró-Alcalde JL, Saurina J (2009) Credit supply: Identifying balance-sheet channels with loan applications and granted loans, vol 7655. CEPR Discussion Paper Series https://doi.org/10.2139/ssrn.1685370

Jimenez-Rodriguez R, Sanchez M (2005) Oil price shocks and real GDP growth: empirical evidence for some OECD countries. Appl Econ 37:201-228

Johnson PO (1959) Development of the sample survey as a scientific methodology. J Exp Educ 27:167-176

Jones DW, Leiby PN, Paik IK (2004) Oil price shocks and the macro economy: what has been learned since 1996? Energy J 25(2):1-32

Kim S, Willett T (2000) Is the negative correlation between inflation and economic growth? An analysis of the effect of the oil supply shocks. Appl Econ Lett 7:141-147

Köhler M (2015) Which banks are more risky? The impact of loan growth and business model on bank risk-taking. J Financ Stab 16:195-212 https://doi.org/10.1016/j.jfs.2014.02.005

Kong Y, Wei F (2017) Financial development, financial structure and carbon emission. Environ Eng Manage J 16(7):1609-1622

Korkmaz S (2015) Impact of bank credits on economic growth and inflation. J Appl Finance Bank 5(1):57-69

Kou G, Chao X, Peng Y, , Yi PENG , Alsaadi F, Viedma E ( 2019) Machine learning methods combined with financial systemic risk, Technol Econ Dev Econ, Article in press: https://doi.org/10.3846/tede.2019.8740

Lane PR, Milesi GM (2007) The external wealth of nations mark II: revised and extended estimates of foreign assets and liabilities, 1970-2004. J Int Econ 73(2):223-250

Lardic, S., \& Mignon, V. (2006). The impact of oil prices on GDP in European countries: An empirical investigation based on asymmetric cointegration. Energy Policy, 34(18):3910-3915.

Lardic, S., \& Mignon, V. (2008). Oil prices and economic activity: An asymmetric cointegration approach. Energy Economics, 30(3):847-855.

Lescaroux F, Mignon V (2008) On the Influence of Oil Prices on Economic Activity and Other Macroeconomic and Financial Variables. OPEC Energy Rev 32(4):267-380

Ministry of Environment and Climate Affairs (2017) Retrieved from https://meca.gov.om/ar/module.php?module=pagesshowpage\&Cat $D=21 \& \mid D=133$. (Accessed Oct 2017)

Neelam T (2014) Impact of bank credit on economic growth in Nepal. NRB working paper, no 22. Niger J Econ Soc Stud 49(1):209-234

Nidhaleddine BC, Waël L (2016) Revisiting the role of inflation environment in exchange rate pass-through: a panel threshold approach. Econ Model 52:233-238

Nkomo JC (2006) Crude oil price movements and their impact on South Africa. J Energy Southern Afr 17(4):25-32

Nkoro E, Uko AK (2016) Autoregressive distributed lag (ARDL) cointegration technique: application and interpretation. J Stat Econ Methods 5(4):63-91

Oladosu G (2009) Identifying the oil price-macro economy relationship: an empirical mode decomposition analysis of US data. Energy Policy 37(12):5417-5426

Pahlavani M, Wilson E, Worthington A (2005) Trade-GDP Nexus in Iran: an application of the autoregressive distributed lag (ARDL) model. Am J Appl Sci 2(7):1158-1165

Pesaran M, Shin Y (1999) An autoregressive distributed lag modeling approach to cointegration analysis. In: Strom S (ed) Econometrics and economic theory in the 20th century: the Ragnar Frisch centennial symposium

Pesaran MH, Shin Y, Smith RJ (2001) Bounds testing approaches to the analysis of level relationships. J Appl Econ 16(3):289-326

Rio conference on environment and development (1992) Retrieved from https://sustainabledevelopment.un.org/milestones/ unced. (Accessed Dec 2018)

Samuel UP, Lionel E (2013) The dynamic analysis of electricity supply and economic development: lessons from Nigeria. J Sustainable Soc 2(1):1-11

Swanepoel JA (2006) The impact of external shocks on south African inflation at different Price stages. J Stud Econ Econometrics 30(1):1-22

Vision of Oman (2020), Sultanate of Oman Supreme Council for Planning. Retrieved From https://www.scp.gov.om/en/Page. aspx?|=14 (Accessed:July2019).

World Development Indicators (WDI) World Bank, 1978-2017. Retrieved on 28-05-2019 from https://data.worldbank.org/

Zhang H, Kou G, Peng Y (2019) Soft consensus cost models for group decision making and economic interpretations. Eur J Oper Res 277(3):964-980 https://doi.org/10.1016/j.ejor.2019.03.009

\section{Publisher's Note}

Springer Nature remains neutral with regard to jurisdictional claims in published maps and institutional affiliations. 